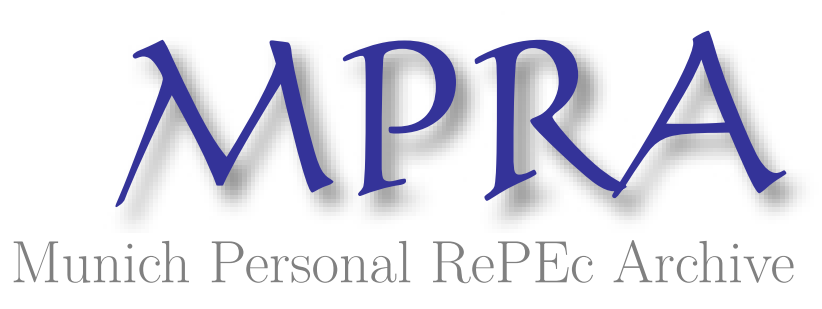

\title{
The Rise and Fall of Gulf Finance House
}

khnifer, mohammed

2010

Online at https://mpra.ub.uni-muenchen.de/27403/

MPRA Paper No. 27403, posted 13 Dec 2010 06:09 UTC 


\section{Design, Implementation and Risk Aspects of Islamic Financial Products and Services}

Spring Term 2010

Reading University

Lecturer: Professor S. Archer

\section{The Rise and Fall of Gulf Finance House}

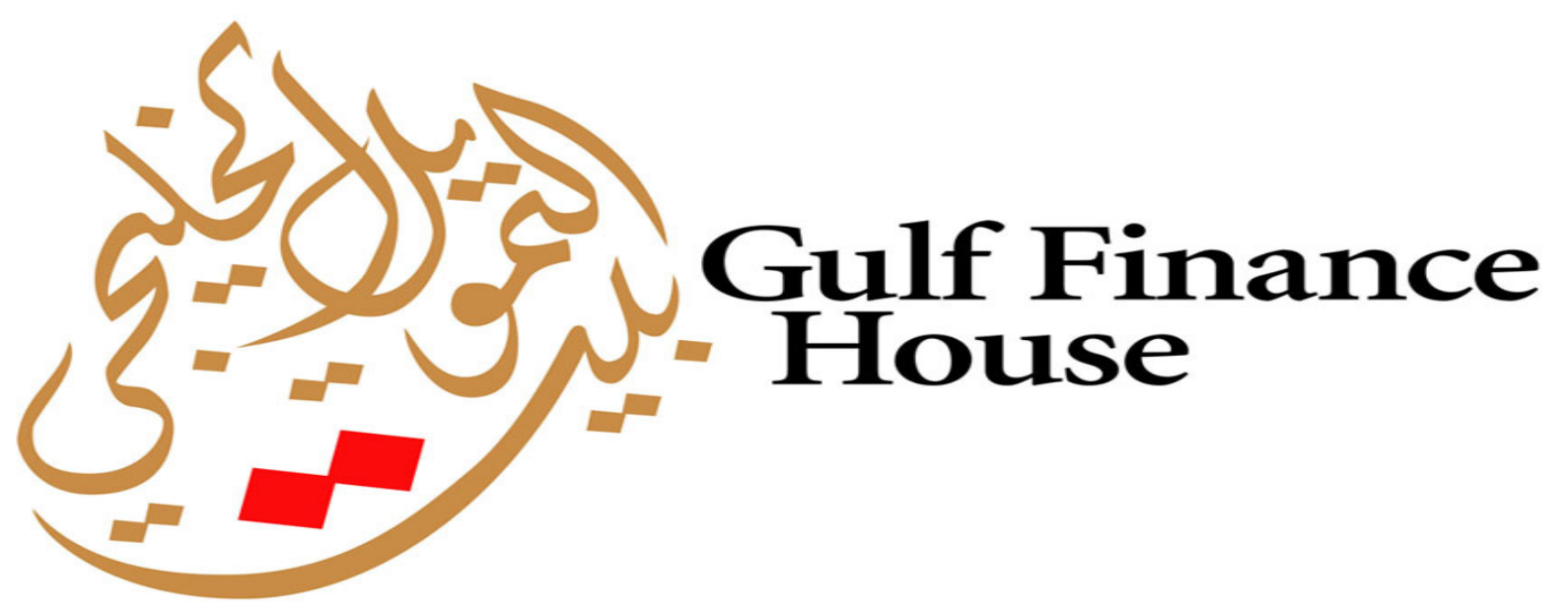

by

Mohammed Khnifer, Aatef Baig, Frank Winkler

All the three authors are holders of an MSc in Investment Banking \& Islamic Finance (IF) from Reading University and a Chartered IF Professional-INCEIF.

Mohammed Khnifer is regarded as part of a 'second generation' of Islamic banking practitioners who have a solid academic background in Islamic finance. He is one of the most prolific and well-known journalist specializing in Islamic Finance today. For the past six years he has been in charge of the editorial content for the Islamic Banking section of $\mathrm{Al}$ Eqtisadiah (Kingdom of Saudi Arabia). mkhnifer@aleqt.com

Mr. Baig has BA Honours in Accounting and Finance from Oxford Brookes University. He worked as Financial Analyst and Auditor for two companies when he was in Kuwait. aatefbaig@hotmail.com

Mr. Winkler has MSc in business studies from Technische University and BSc in economics from Albert-Ludwigs-University. He worked as Corporate \& Investment Banker when he was in Germany. f.r.winkler@ hotmail.de 


\section{Table of Contents}

1 Introduction 3

2 Analysis of GFH Business Model 3

2.1 Property Crash Brings Impairment Provisions 3

2.2 Failure of Risk Management 5

2.3 Nonsustainable Revenue 5

3 Focus: GFH Private Equity Model 6

3.1 Traditional vs. Islamic Private Equity 6

3.2 The GFH Private Equity Model and the "Premium" 9

3.3 Implementing Murabaha with Private Equity 11

3.4 Explaining How GFH Suffered Losses from its 11

Unique Private Equity Model

4 GFH, Recipe for Disaster 13

4.1 Lack of Diversification 13

4.2 Maturity Mismatching 13

5 Liquidity Shortage Leads to the Downfall 14

5.1 Reputational Risk and Money Markets 14

5. 2 Financial Distress 15

5.3 Sub-investment-Grade Rating 15

5.4 Looming Threat of D Rating 16

6 Conclusion 16

$\begin{array}{ll}7 \text { Reference List } & 17\end{array}$

8 Appendices 19 


\section{The Rise and Fall of Gulf Finance House}

\section{Introduction}

Gulf Finance House (GFH) is a Shariah compliant Islamic wholesale investment bank established in 1999 in Bahrain (Arabian Business, 2010). The company is currently listed on the Kuwait and Bahraini stock exchanges, the Dubai Financial Market and on the London Stock Exchange, and became the first Islamic investment bank in the Middle East to be traded on the London Stock Exchange (ArabianBusiness, 2010).

The bank claims to be active in five separate lines of business:

- Development infrastructur (called real estate)

- Venture capital

- Private Equity

- Investment Banking

- Asset Management

GFH deals with nearly 3,000 affluent private clients and institutional investors (Goeksenin, 2009). Corporate growth historically was based on the origination of development infrastructure projects, i.e., conceiving projects on a greenfield basis and starting from the concept stage. These projects were mostly related to new real estate developments, although there were also some industrial projects. The areas of business included the GCC region, emerging markets and in the Middle East \& North Africa (MENA) region, as well as in Europe and North America.

The core business of GFH has been private equity, and most of this was in new real estate projects. Looking at the GFH income statements from 2004 through 2008 it appears $70 \%$ of their entire business activities were solely on one form or another of greenfield real estate projects (Gulf Finance House, 2010)(see Appendix "Investment and project launches").

During its first seven years of operations, GFH launched projects and investments with an aggregate final value exceeding US $\$ 12$ billion. Its diversified investment portfolio includes mega real estate developments such as the US $\$ 1.3$ billion Bahrain Financial Harbor, the US\$1.6 billion Energy City Qatar, and the US\$3.8 billion Legends in Dubai Land. In addition, GFH has numerous funds targeting investments in the Middle East, Africa, Asia, Europe and the Americas (Zawya, 2010).

\section{2- Analysing GFH Business Model}

\section{1 Property Crash Brings Impairment Provisions}

GFH was heavily involved in real estate-related Private Equity (P/E) deals and real estate-related infrastructure projects. As both of these businesses brought GFH, 
eventually, to its knees, we will examine here the results of heavy real estate development concentration on the bank's operating profit. To begin with, the bank's operating activities generated a 2009 net loss of nearly US\$728m of which US\$607 was announced in the last quarter (Fitch, 2010). Compared to 2008, there was a decline of approximately $350 \%$ in the net income (net income in 2008 US\$292m).

Perhaps GFH's end-of-year results can symbolize the property bust in the GCC region. For example, due to an impairment loss in 2009 the bank 's total assets fell from US\$3.49 in 2008 to US\$ 1.64 billion at the end of December 2009 (a drop of $53 \%$, or nearly $\$ 2$ billion). The amount for the impairment allowance represented an increase of $1539 \%$ compared to 2008 (approximately US\$ 40 million) and an increase of $4273 \%$ in comparison to 2007 (around US\$15 million) (GFH Financial Statement, 2009).

As one would expect these massive asset impairment provisions affect the bank's ability to fulfil its commitments on current headline projects like Dubailand and at least three of their four Energy city projects (Qatar, Libya, Kazakhstan and India), if not all four. For its Dubai property project, for example, the bank was forced to book a provision of US\$270 million (Soorani, 2010). Because of the dramatic decline in real estate values throughout the Gulf region the project (started in 2004) was suspended. Today, despite having been suspended the project still represents a large asset on the bank's balance sheet (Goeksenin, 2009).

The remaining US $\$ 305$ million provisions are booked on the bank's exposure to infrastructure projects including the Energy Cities, industrial companies, recreational parks (Lost Paradise), and investment in funds and financial institutions (Injazat Capital Limited and Qinvest) (Soorani, 2010). It is worth of mentioning that GFH is currently the project manager for most of these projects (undertaken through SPVs) and hence the fate of these projects might depend on the survival of GFH. This could represent a much bigger risk not only for GFH and its projects, but also for the broader Bahraini banking sector.

As a final note, it's worth mentioning that GFH write offs in 2007 and 2008 were very modest compared to the 2009 write offs. This leads one to suspect that the bank may have been mis-stating the true value of its assets. The global financial crisis was fully evident by the end of 2007, and by the end of 2008 there were almost no investment sectors worldwide that had not experienced dramatic value declines. U.S. and European private equity firms openly stated in their year-end financial statements that assets declined anywhere from $15 \%$ to $25 \%$ or more. Yet despite this GFH declared only US $\$ 15,362,000$ write offs of asset values in 2007 , and only US\$39,127,000 in 2008. Then, perhaps finally forced to admit the true losses of GFH assets, valuations were written down a total of US $\$ 655,598,000$ in the 2009 fiscal year.

Of course this is simply speculation. There is no evidence of wrongdoing, and GFH's financial statements were prepared by an independent accounting firm. But, the apparently very late announcement of massive impairments does leave one to question the company's responsiveness to shareholders, investors, regulators and the public generally. 


\subsection{Failure of Risk Management}

By analysing the background of 2009 losses, we can deduce that a) GFH was in the middle of an unprecedented real estate valuation collapse following an equally unprecedented real estate valuation bubble, and b) that GFH had a majority of nearly every aspect of its valuation and business model tied to real estate. Unfortunately for GFH there seems to have been no pre-crisis efforts to diversify the business away from a single sector, and a single type of earnings.

GFH faced four traditional risks: market risk, operational risk, liquidity risk and credit risk. Its absence of any meaningful diversification amplified some of those risks, but especially market and liquidity risks (Goeksenin, 2009). GFH also faced sector concentration risk. This risk is especially when looking at the bank's asset distribution. In 2009, 83,4\% of total assets (US\$1.64 million) were concentrated in the GCC countries, whereas $16.6 \%$ were in MENA, Asia, Europe and the United States (GFH Financial Statement, 2009). The same asset concentration can be applied for the year 2008, when GFH reported $78.5 \%$ of assets were in the GCC region.

GFH's operational risks including exit risk and the reputation risk, especially important given the bank's very difficult situation now in a sluggish business environment. Credit risk on the other hand only played a minor role in the fall of GFH as the bank acts as an intermediary between regional investors and the investment projects in which GFH guides their money. GFH had, in fact, probably very little actual cash in any of the deals it sponsored, instead funding its minority positions with what became known in Bahrain and the region as the "premium" (see more on this below), and was therefore less at risk (Goeksenin, 2009).

\subsection{Nonsustainable Revenue}

With the above is being said, it is clear that GFH had a volatile earnings stream and was far from diversifying away from private equity investments in brand-new real estate projects that were years away from generating cash flow. Unfortunately GFH's public relations department provides a somewhat misleading view. "This agreement [referring to a loan renegotiation] is indicative of lenders' confidence in GFH's business model, its ability to generate sustained revenue and return to profitability" said GFH Chairman Dr. Esam Janahi (Arab Times, 2010). His argument can be easily refuted by a glance at the bank's financial statements; the business was not sustainable at all. This can be proven, by looking at the revenues and expenses over a period of 5 years (see graph 1). 


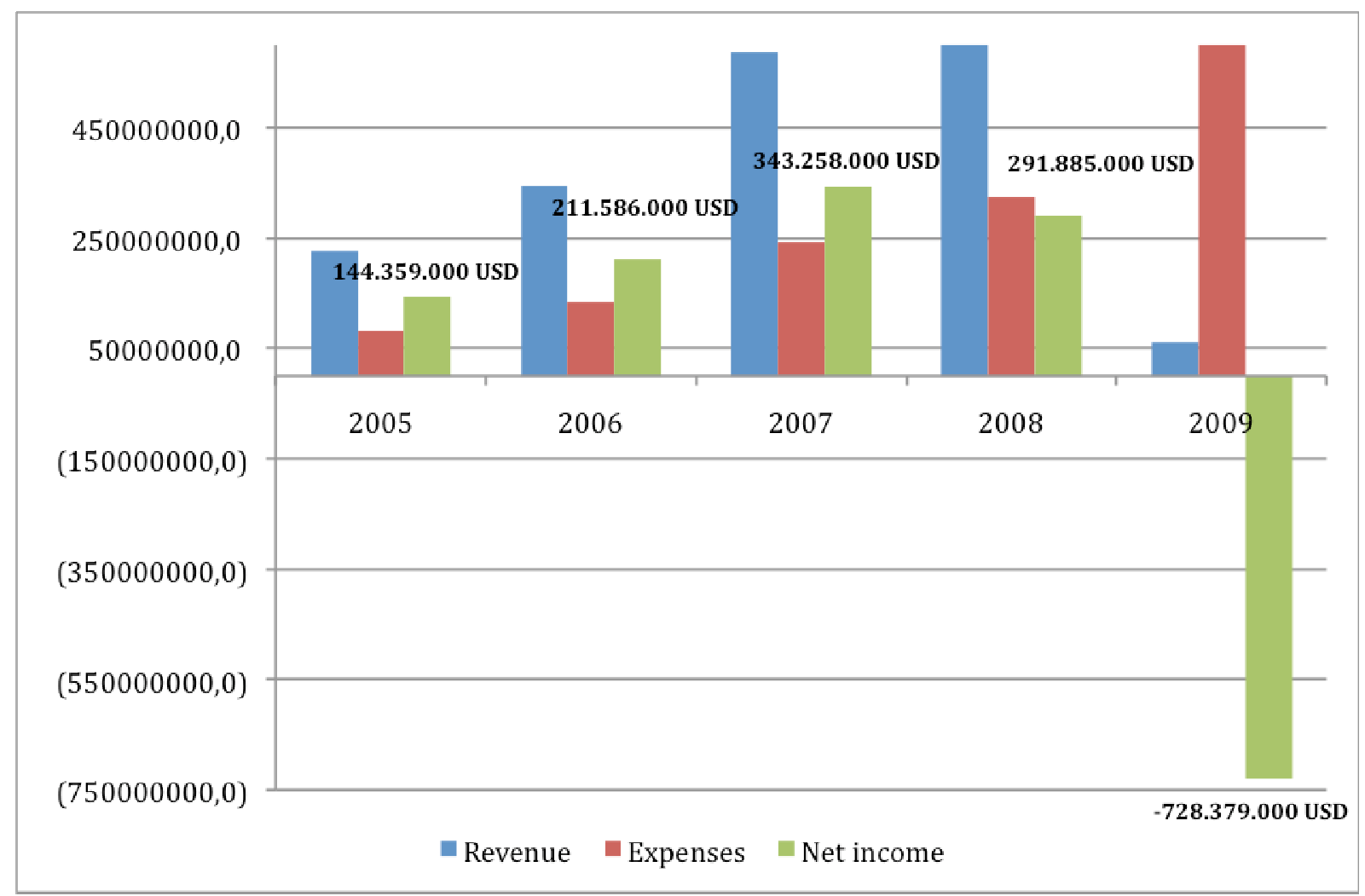

Graph 1: Net Income, Revenue and Expenses from the GFH between 2005 and 2009 (Source: Gulf Finance House Annual Report 2005, 2006, 2008, 2009)

In the above graph we see a company with growing revenue and profits, up until the fateful year of 2009. Losses in 2009 almost wipe out the previous four years of profits, and in fact wipe out all profits and generate a cumulative loss when one assumes zero value for the footnoted item, "Income from receiving shares in companies in which the bank invested, in lieu of cash," a line item that variously provided from $8 \%$ to $30 \%$ of annual revenue, but delivered no cash:

\begin{tabular}{|l|r|r|r|r|r|}
\hline & $\mathbf{2 0 0 5}$ & $\mathbf{2 0 0 6}$ & $\mathbf{2 0 0 7}$ & $\mathbf{2 0 0 8}$ & $\mathbf{2 0 0 9}$ \\
\hline $\begin{array}{l}\text { Income from receiving shares } \\
\text { in companies in which the bank } \\
\text { invested, in lieu of cash }\end{array}$ & $17 \%$ & $30 \%$ & $8 \%$ & $21 \%$ & $0 \%$ \\
\hline
\end{tabular}

\section{3- Focus: GFH Private Equity Model}

\subsection{Traditional P/E VS. Islamic P/E}


As mentioned above, most of GFH's deals were private equity which comprising never less than $70 \%$ of its revenue. It should have been abundantly clear to management that any annual failure in the bank's private equity business would directly result in the failure of GFH. Therefore, in order to comprehend the fall of GFH, it is important to understand the basic mechanism of private equity, as well as the adaptation of private equity used by GFH.

According to IFSL $(2009$, p.2) "Private equity is a broad term that refers to any type of equity investment in an asset in which the equity is not freely tradable on a public stock market. This also includes public companies that are delisted as part of the transaction."

The fund raising process begins when private equity houses establish a specialpurpose vehicle (a "fund") then raise capital from institutional investors, such as pension funds, and high net worth individual. These investors are collectively referred to as limited partners (LPs, although GFH did not necessarily use the GP/LP structure, it was essentially the same). The year in which the capital is raised and invested for a given transaction is known as that transaction"s "vintage" year. Once set up a fund is generally closed to new investment. A private equity firm's track record on previous funds will drive its ability to raise capital for future funds. The general partners (GPs) - the private equity firms - invest this capital according to a business plan approved by the LPs in the process of raising the money. To increase the impact of the investment in a target company or real estate project the GP often borrows from banks and other lenders on behalf of the fund.

Once the value-adding process has finished and the private equity firm believes that it has increased the business' efficiencies-usually in 5 to 7 years- the GP seeks an exit to realise returns on the investments made by the LPs. The main exit routes include trades sales, repurchase, refinancing and floatation on a public exchange (BVCA, 2010).

Most private equity firms, set up as private partnerships, charge the investors an initial purchase fee equal to 1.5 to 2.0 percent of assets committed, and then an annual management fee of about the same amount, which is supposed to be used to finance operations of the private equity firm (salaries, office rent and other day to day costs) (Private Equity Council, 2007). Typically a private equity house will seek an overall return in terms of an annual internal rate of return (IRR), calculated over the life of the investment, of above 20 percent per annum. Although the return will depend on the risk of the investment, generally the higher the risk the higher the return that is expected (BVCA, 2010).

It is important to note that private equity is almost always totally illiquid as capital is usually locked up for the 5 to 7 year period, but it is not unusual for investments to be 
locked up for ten years until there is an exit. Historically, and in retrospect we know why, private equity firms in the United States and elsewhere occasionally delivered profits of $15 \%$ to $25 \%$ per year to their investors. What was often unsaid, however, was the frequency of failure in the industry. A study by Bain \& Co. revealed that " 40 percent of private equity deals fail to earn returns that even cover their original acquisition costs...."(Goliath 2007).

Sophisticated investors know this. They will seek private equity firms that have a solid track record, and they will diversify their investments among funds at one private equity firm, and then among several private equity firms. Very sophisticated institutional investors will also maintain minimal amounts of total private equity investments. According to one report, global private equity was equal to only $1.2 \%$ of all private wealth under management (Sandwick, 2008). A private equity firm itself will also try to achieve diversification. It will spread its talent and resources among several funds in various industries, plus as is often the case it will branch into other lines of business to reduce total reliance solely on private equity (such as at Investcorp, also in Bahrain). This will facilate dispersion of risk and spread the financial faliure of a venture over the total investment held by the fund and ultimatelt over all the individual investors. ( Wouters, n.d.)

\section{Basic IPEF fund structure}

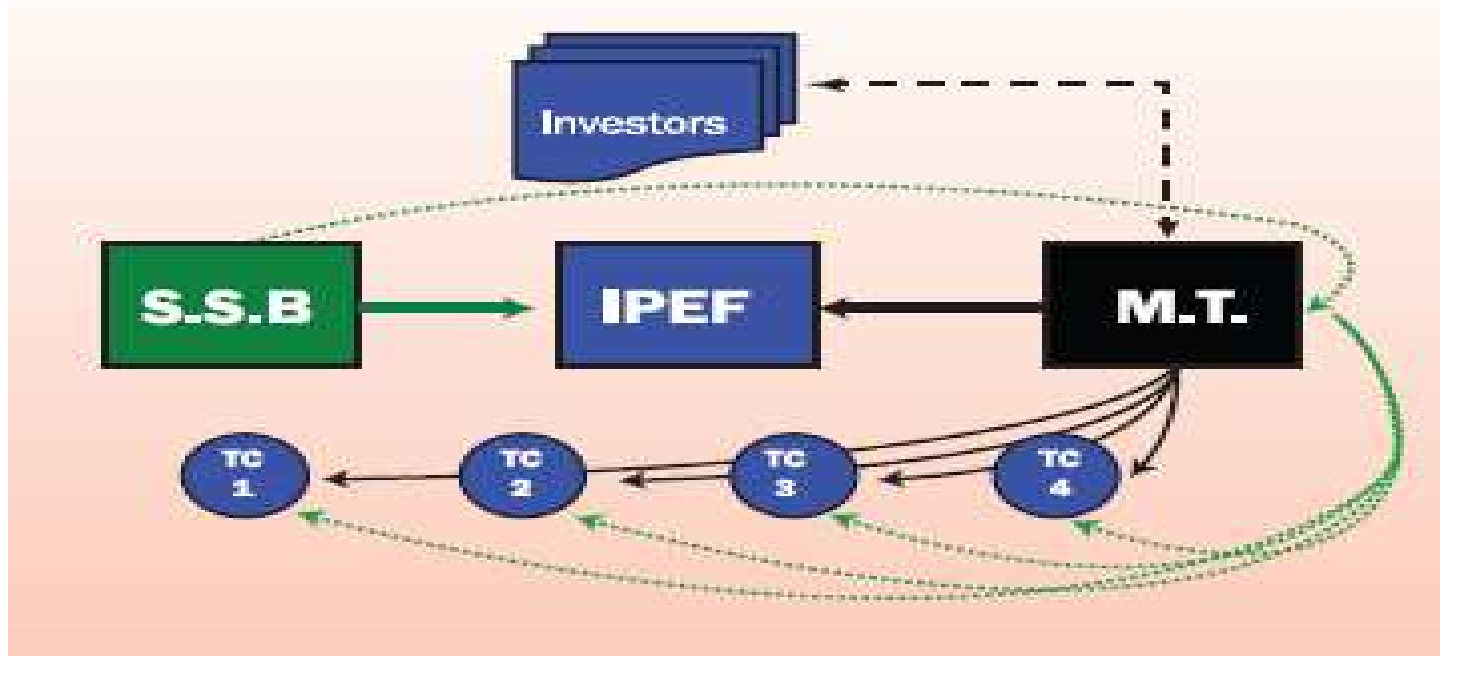

Source: Wouters, p.3

As seen above, there is very little structural distinction between conventional private equity funds (CPEF) and Islamic private equity funds (IPEF).

Similar to CPEF, IPEFs will invest in the underlying target companies and will upon the future exit incur losses or gain profits, which are passed on to investors. They also 
charge identical purchase commissions and management fees, and they always add a performance fee to the final return if profits are above some minimum threshhold. The performance fee is generally $15 \%$ to $20 \%$ of the total return to investors above say 5\%. The point here is that the CPEF does not achieve a major payout until it successfully exits an investment. The objectives of the CPEF (or GP), in other words, is closely aligned with the objectives of LP investors.

IPEF can be distinguished from CPEF in several other ways, such as investment techniques excluding the use of conventional debt for buyouts or conventional project debt (although Islamic credit facilities can and are substituted for conventional debt). One substantial difference is the inclusion of a Shariah supervisory board (SSB), one of whose several functions is to list eliminating criteria's used for short listing target companies.

\subsection{The GFH Private Equity Model and the "Premium"}

Understanding the conventional Private Equity model helps us understand the modifications of this model used by GFH. In general, GFH pioneered in the GCC region the addition of an large upfront fee, a relatively large amount of money at the time GFH made its Private Equity invesment on behalf of LP investors. This is unique and, to our knowledge, unprecedented in the Private Equity industry anywhere.

GFH would normally find a target investment, most often a greenfield real estate project but also companies or pools of real estate in Europe or North America. It was then taken under GFH's control, either through direct acquisition of the asset on GFH's balance sheet, or control of the project through an SPV created by GFH.

GFH would then create a fund offering memorandum and send its sales force out to meet LP investors. Happy with the investment prospectus the investors would then transfer money to GFH. A new SPV created by GFH, or the previous SPV, would then transfer majority ownership of the asset to the LP investors.

Until this point the process was in line with industry standards. However, it appears GFH would charge a "premium" to LP investors. Say, for example, GFH bought a mid-sized American company for $\$ 10$ per share. It would then sell a majority of its position to the LP investors for $\$ 15$ per share, making an immediate 50\% profit on its investment. Sometimes this was done in an all cash transaction, sometimes in a combination of cash and the above-mentioned "Income from receiving shares in companies in which the bank invested, in lieu of cash." This extra bonus became commonly known as the "premium." 
In effect, money acquired from LP investors for real estate projects and other private equity investments was a charged the exit fee, or performance fee, in advance, a preexit fee ( Maktoob Business, 2010). The GFH model for charging the performance fee in advance became widely emulated throughout the GCC region, used by peer firms Arcapita, Addax, GBCorp, and many other. This was to our knowledge unique in the world industry of private equity. It seems to be a extremely profitable strategy as the GPs (GFH in our case) made enormous profits on an investment using LP money before a successful exit. Oddly enough, all of GFH's investments with LPs also carried a performance fee, which would if the investment was successful truly deliver enormous profits to GFH.

This kind of lopsided fee structure was obscured in part because of the very favorable market conditions that existed during the boom years of late 2002 through 2007, when asset prices were inflating everywhere, but in particular in real estate. However, it would only take a modest crisis to expose the inequal application of GFH's fees. With a recession and deflating asset values GFH would ultimately have to disclose substantial capital loss to its investors. And, that is precisely what has happened.

During the boom years GFH launched a series private equity and real estate projects. In the table below we can see the annual income from investment banking activities, which were by far the vast majority of revenue at GFH. Income is broken into two line items, cash and shares, both received as fees for GFH activities. Since GFH exited very few investments during this time period we can assume nearly all the revenue was from buying assets, not managing or selling them. Interestingly, GFH chose to accept a large volume of revenue in the form of shares in the SPVs it created.

\begin{tabular}{|c|c|c|c|c|c|}
\hline & 2005 & 2006 & 2007 & 2008 & 2009 \\
\hline $\begin{array}{l}\text { Income from investment advisory } \\
\text { services/investment banking } \\
\text { services (the "premium") }\end{array}$ & $129,023,000$ & $93,326,000$ & $355,709,000$ & $323,191,000$ & $48,980,000$ \\
\hline $\begin{array}{l}\text { Income from receiving shares in } \\
\text { companies in which the bank } \\
\text { invested, in lieu of cash }\end{array}$ & $38,729,000$ & $74,426,000$ & $44,471,000$ & $130,000,000$ & 0 \\
\hline $\begin{array}{l}\text { Placement, arrangement \& } \\
\text { management fees }\end{array}$ & $27,280,000$ & $20,337,000$ & $13,421,000$ & $33,233,000$ & $2,580,000$ \\
\hline Total income & $\$ 222,926,000$ & $\$ 246,811,000$ & $\$ 587,983,000$ & $\$ 617,586,000$ & $\$ 62,175,000$ \\
\hline $\begin{array}{l}\text { Investment banking income as \% } \\
\text { of total income }\end{array}$ & $87 \%$ & $76 \%$ & $70 \%$ & $79 \%$ & $83 \%$ \\
\hline $\begin{array}{l}\text { Placement, arrangement } \& \\
\text { management fees as } \% \text { of total } \\
\text { income }\end{array}$ & $12 \%$ & $8 \%$ & $2 \%$ & $5 \%$ & $4 \%$ \\
\hline
\end{tabular}


But, GFH became highly exposed when the crisis hit. Its private equity business ground to a halt. Income from investment banking services collapsed, from a high of $\$ 453$ million in 2008 to a low of $\$ 49$ million just the next year. Clearly GFH was unable to sustain revenue in its core line of business. It was fully exposed to a single business line, private equity, and its revenue was dependent on LP investors continuing to accept the concept of the premium, which apparently they did not.

As one would predict, actual management fees were a small minority of GFH's revenue model. The line item "Placement, arrangement \& management fees " was once as high as $12 \%$ of total revenue, but otherwise only in the mid to low single-digit percentage range. Clearly GFH was not a sustainable enterprise without constant deal flow and buying assets with LP investor money.

\subsection{Implementing Murabaha with Private Equity}

Our analysis shows that the GFH investment model implemented was not quite a private equity. The form may be private equity but the substance may not. GFH was undoubtedly engaged in the purchase and sale of assets, although it appears the large majority of its revenue was from purchasing or acquiring assets with LP investor funds, not exiting investments. Therefore, we like to theorise that GFH may have implemented a modified version of Murabaha in its Private Equity deals.

A traditional Murabaha transaction under Shariah law must meet the conditions of a valid sale. In addition to that it is a requisite that the seller informs the buyer of the cost price of the subject matter and any additional cost and profit (which is pre agreed) it is intends to charge (Ayub, 2007). The only difference in GFH's Murabaha model was that they did not disclose the profits it was charging on the projects to LP investors but rather valued them in a way that included profits and sold them to the LP investors through a fund. Hence, the pricing model used by GFH to price their deals can be linked to the type of model one would find in a Murabaha transaction.Indeed, This technique is flawed and its implication can be directly seen on the current financial condition of GFH.

\subsection{Explaining How GFH Suffered Losses from its Unique Private Equity Model}

With the credit crisis GFH was not left unscathed as the Islamic investment bank wrote down $\$ 728$ million in the year 2009. After examining these specific provisions, some Private Equity ventures, despite the lack of transparency from GFH's side, were included in the write-down such as Injazat Capital Limited. In a typical Private Equity deal the company does not commit its own money into the funds, investors do. GFH, following industry practice, placed little of its own money into any of the transactions 
it sponsored. However, unlike common industry practice, GFH normally took a significant cash and shares at the beginning of each investment, or what became widely known as the premium.

It was hard for us to justify how GFH suffered losses from its Private Equity deals as there was some lack of disclosure on the innovative mechanism used these deals. Nonetheless, we managed to come out with a logical explanation after discussions with various bankers, including John A. Sandwick ,a specialist in Islamic finance in Geneva, Switzerland.

GFH committed little or no of its own funds into the Private Equity SPVs it sponsored over the years, yet ended up holding significant minority positions in all of them via the premium. Perhaps GFH used these large minority positions to make LP investors confident becuase the bank had the appearance of being in line with the expectations and objectives of the LP investors, although they may not have known the size and extent of GFH's rewards on entering a transaction, or its "premium." This strategy backfired when the various GFH SPVs collapsed in value, which appears to finally have been fully disclosed in the 2009 financial statements.

While GFH suffered enormous balance sheet losses from writing off large amounts of its previously-earned "premium" shares, it also began losing money on an operating basis, too.

\begin{tabular}{|l|r|r|r|r|r|}
\hline & $\mathbf{2 0 0 5}$ & $\mathbf{2 0 0 6}$ & $\mathbf{2 0 0 7}$ & $\mathbf{2 0 0 8}$ & $\mathbf{2 0 0 9}$ \\
\hline Staff costs & $40,103,000$ & $67,248,000$ & $103,798,000$ & $134,542,000$ & $29,381,000$ \\
\hline $\begin{array}{l}\text { Investment advisory } \\
\text { expenses }\end{array}$ & $29,402,000$ & $25,055,000$ & $48,351,000$ & $48,524,000$ & $26,571,000$ \\
\hline $\begin{array}{l}\text { Murabaha } \\
\text { expense/financing cost }\end{array}$ & $8,022,000$ & $24,322,000$ & $56,482,000$ & $63,507,000$ & $39,578,000$ \\
\hline Other expenses & $5,015,000$ & $10,767,000$ & $20,732,000$ & $39,416,000$ & $39,426,000$ \\
\hline Total expenses & $\mathbf{\$ 8 2 , 5 4 2 , 0 0 0}$ & $\mathbf{\$ 1 2 7 , 3 9 2 , 0 0 0}$ & $\mathbf{\$ 2 2 9 , 3 6 3 , 0 0 0}$ & $\mathbf{\$ 2 8 5 , 9 8 9 , 0 0 0}$ & $\mathbf{\$ 1 3 4 , 9 5 6 , 0 0 0}$ \\
\hline
\end{tabular}

The chart above shows GFH's core operating expenses. They were a modest $\$ 82$ million in 2005, but ballooned around $280 \%$ just two years later, and almost $350 \%$ in three years. One has to wonder whether the GFH management was fully aware of the company's ongoing high and ever-increaing fixed cost structure in light of the fragility of its revenue model, a model designed solely on the company's ability to raise private investor money and buy assets to gain a large premium. 
Certainly GFH tried to cut costs. That is evident in the 2009 figures, where staff costs were cut almost $80 \%$. If this was not due to staff reductions then it was due to huge shrinkages in the pay packages received by employees.

But, having built a machine that fed on the premium GFH was unable to stave off the credit crisis any longer. The nearly $\$ 730$ million in losses in 2009 for a firm that had unreasonably high profits in all previous years indicates the party was over. GFH had finally come down to earth.

\section{GFH Recipe for Disaster}

\subsection{Lack of Investment Diversification}

Probably one of the most important lessons in the GFH case is the fact the bank could not manage to diversify its business model prudently. "With GFH, they don't have a business model at this point and their revenue streams have dried up. The balance sheet is a mess and they don't have sufficient liquidity to meet near-term refinancing," said Karthik Sankaran, an analyst at Bank of America Merrill Lynch who covers the company's stock (Fitch, 2010). The bank mainly relies on the intermediation of greenfield real estate and investments in infrastructure projects. The figures for 2005 to 2009 show that there was no real diversification in the business income sources. In each of the years under review revenue from investment advisory service/investment banking services and "Income from receiving shares in companies in which the bank invested, in lieu of cash" vastly greater than the revenues received in any other line of business (see Appendix, Gulf Finance House Income Statement 2005 to 2009). This lack of diversification, and the heavy reliance on the premium, was finally GFH's undoing.

\subsection{Maturity Mismatching}

Retail banks differ from investment banks as they rely on depositors to fund them, whereas the latter depends on first and foremost a pool of eager LP investors, and later on wholesale deposits and term loans or bonds. This is identical in Islamic banking, where retail Islamic banks rely on customer deposits and Islamic investment banks rely on LP investors, wholesale deposits and term Islamic credits or sukuk to fund their activities.

GFH's management failure was evident in the rollover of term Islamic credits. We suspect LP investors simply stopped investing in GFH transactions sometime in 2007, 
and had significantly slowed the flow of new money even earlier. To feed its expense machine and make new investments GFH seems to have began relying on wholesale markets and Islamic term credits and sukuk to finance its business. We saw the extreme difficulty GFH had to refinance these debts when they came due, where it was nearly impossible to simply rollover existing facilities. This is because lenders saw that GFH had most of its assets in very long-term investments, none or few of which could be sold to meet cash requirements. The company was completely illiquid.

GFH was caught off-guard when the credit crisis hit as it was difficult to refinance debts coming to maturity and difficult or impossible to exit from investments to unlock liquidity, all during a market where liquidity had dried up and asset valuations had collapsed. Indeed, GFH would need longer-term funding sources and new business activity because its debt structure is short-term and operating cash flow is minimal (Standard and Poor's, 2010).

\section{Liquidly Shortage Leads to Downfall}

\subsection{Reputational Risk and Money Markets}

In the fourth quarter of $2008 \mathrm{GFH}$ began to feel the heat of the financial crisis as they witnessed a plunge in income from placement fees. For nine years, high-net-worth individuals were pouring funds into GFH's Private Equity deals and suddenly these funds came to standstill. GFH suffered from what appeared to be a reputational risk in 2008 and most certainly in 2009, as investors came to realize the full extent of their losses after property markets crashed.

Further explanation for that can be that GFH was good in buying assets, not from managing or exiting assets. Huge portions of its private client funds are still tied up in these totally illiquid Private Equity ventures. Clearly LP investors had had enough, as GFH did not manage to sponsor a single major deal in 2009, and where its investment banking income (which we presume still mostly comprised of the fabled "premium") was only $\$ 48$ million compared with $\$ 323$ million the previous year and $\$ 355$ million two years earlier. Without doubt when Private Equity asset purchases represent the large majority of one's business, as was the case with GFH, then definitely one's revenue stream will be disrupted at the first hint of recession.

As mentioned above, when fresh funds stop flowing in from private investors and a large fixed cost base exists, there is little choice for an investment bank like GFH but to borrow from the markets. GFH seems to have replaced private investor funding with a $\$ 200$ million sukuk and two Islamic loans (reverse Murabahah and Wakalah) from other lenders in the 2008 and 2009 fiscal years. 


\subsection{Financial Distress}

Beginning in 2010, and coupled with its inability to raise fresh funds, GFH was clearly in a financial distress situation. GFH's Capital Adequacy Ratio (CAR) dropped to $12.9 \%$ as of December 2009 (16.1\% at December 2008), marginally higher than the Central Bank of Bahrain (CBB)'s 12.0\% requirement (Soorani, 2010). The bank's auditors (KPMG) have also pointed out the low CAR level in their audit report. A low CAR restricts GFH's ability to absorb possible future losses or take additional exposure, unless capital is increased (Soorani, 2010).

After registering the biggest loss ever for an Islamic financial institution last year, GFH knew that the wholesale loan and sukuk markets would remain largely closed to Bahrain's off-shore investment houses ( khnifer, 2010). In September 2009, it sponsored a $\$ 300$ million recapitalization, but the cash was quickly disbursed and again by year's end GFH was known to have almost no cash left. GFH then announced it replaced a $\$ 300$ million Murabahah loan that matured in February 2010 with a new $\$ 100$ million facility with a maturity of six months, having repaid the other \$200 million (khnifer, 2010). But for a financial distress institution, the newly renegotiated terms were quite high. It was reported then that GFH was paying a profit rate of 500 basis points over LIBOR and an extension fee of 100 bps for its $\$ 100$ million, six-month syndicated loan (khnifer, 2010).

\subsection{Sub-Investment Grade Rating}

In a region that sits on the world's largest oil reserves, it was uncommon to have a sub-investment rating (i.e., lower than BBB-) for a banking entity, but GFH came to define that concept. In a move that might be interpreted as misleading for retail investors, GFH's public relations department was marketing the completed renegotiation of $\$ 300$ million Murabahah loan as a "success." However, Standard and Poor's had another view. Right after hailing the renegotiations as a success on 10 February 2010, the international rating agency lowered its long- and short-term counterparty credit ratings on GFH to SD/SD (selective default) from CC/C. "Under our criteria, we consider GFH's maturity extension to be a 'distressed exchange' and therefore tantamount to a default, because the new maturity represents a change to the facility's originally scheduled payment terms," said Standard \& Poor's credit analyst Emmanuel Volland (Standard and Poor's, 2010). An 'SD' rating is assigned when Standard \& Poor's believes that the obligor has selectively defaulted on a specific issue or class of obligations ( khnifer, 2010). For a business model that relies on raising funds from clients and place it in its ventures this represents an enormous blow to reputations and credibility, as well as the ability to raise fresh capital.

In February 2010 GFH was in a critical financial position as it was one notch away from D (Default), but not for long. On 3 March 2010 Standard and Poor's raised its GFH rating to CCC-/C from SD/SD with negative outlook. "The rating action follows GFH's completion of the partial extension of maturity of a $\$ 100$ million 
facility which is set to be repaid in five installments over the next two years," said Standard \& Poor's credit analyst Goeksenin Karagoez (Standard and Poor's, 2010). This was barely a move in the right direction, but once again GFH's public relations department declared the modest improvement a success. S\&P was more pessimistic, having deemed the bank to have very weak liquidity position from a rating standpoint because it still faces challenges to meet debt repayments coming due in the very near term (khnifer, 2010).

\subsection{Looming Threat of D Rating}

It is commonly known that one of the indirect cost of being in a financial distress situation is laying off staff. GFH was no exception. Recently statements say that GFH aims to cut expenses by between 40 and 45 per cent, and has already laid off nearly 100 people, consolidated its nine floors of office space in the Bahrain Financial Harbour and cancelled last year's bonuses (Fitch, 2010). In an attempt to survive, GFH officials have outlined an aggressive plan to sell off assets, cut costs and move into new business areas. (Martin, 2010). However, it is unlikely for the bank to get optimal prices for selling its assets which may result in driving the institution to to further impairments and potential losses (Soorani, 2010). S\&P, on the other hand, remains uncertain regarding GFH's ability to implement its plan for improving its liquidity position and boosting its revenues. $\mathrm{S} \& \mathrm{P}$ went on to give a direct threat by saying that "failure to meet any of the upcoming existing or restructured payments would lead us to lower the ratings to D (Standard and Poor's, 2010).

\section{Conclusion}

GFH was once a household name in the Islamic Investment sphere, before falling from grace. They were a pioneer in bringing Islamic investment banking to legions of investors in the GCC region. But, they also were a pioneer in developing a highly questionable Private Equity business model that hugely rewarded GFH before investments matured, in other words reversing the order of the success fee from the end to the beginning of a transaction. GFH shrewdly made alliances with the GCC media, which resulted in private clients rallying behind GFH projects for several of the boom years, when asset prices were inflating everywhere. That trust was broken when investors discovered flaws in the GFH business model, and finally the financial media disclosed GFH's inability to raise new funds or rollover existing debts, not to mention collapsing valuations of their investments.

Everything changed when the credit crisis reached the Gulf's shores. After damaging its reputation, GFH learned the hard lesson ,i.e., always diversify your business activities. For now, GFH is trying to stand up on its feet by implementing aggressive restructuring plans from within. Nonetheless, we think it is imperative for GFH to sell its prized assets if it wants to recover from its financial distress. We should also note that further provisions equal or exceeding last year's magnitudes are likely, which might mean the bank is on the brink of bankruptcy. But that remains to be seen in the coming months. 


\section{7- Reference List}

Arabtimes (2010). GFH says lenders OK loan refinancing, repays \$200m, [online], retrieved on 3rd March 2010 from Arabtimes :

(http://www.arabtimesonline.com/NewsDetails/tabid/96/smid/414/ArticleID/149453/r eftab/69/Default.aspx)

Arabian Business (2010), Companies- The Gulf Fincane House, [online], retrieved on 6th March 2010 from Arabian Business: (http://www.arabianbusiness.com/financialmarkets/companies/46/profile.)

Ayub, M. (2007). Understanding Islamic Finace. Wiley finance series. Chichester, Wiley.

BVCA (2010). A guide to private equity, [online], retrieved on 7th March 2010 from BVCA:

(http://www.bvca.co.uk/PEVCExplained/features/AGuidetoPrivateEquity2010)

khnifer, Mohammed (2010). Islamic Financial Institutions are Being Hunted with Default Danger, [online], retrieved on 13th March 2010 from Aleqtisadiah newspaper : (http://www.aleqt.com/2010/02/28/article_356190.html)

Fitch, A. (2010). GFH chairman leaves Khaleeji bank, [online], retrieved on 9th March 2010 from The National:

(http://www.thenational.ae/apps/pbcs.dll/article?AID=/20100216/B

USINESS/702169952/0/rss)

Fitch, Asa (2010). Innocent bystander takes hit, [online], retrieved on 13th March 2010 from The National:

(http://www.thenational.ae/apps/pbcs.dll/article?AID=/20100228/BUSINESS/

702289958/0/ART)

Goliath Business (2007) Private equity and corporate governance, [online], retrieved on $5^{\text {th }}$ march 2010 from: (http://goliath.ecnext.com/coms2/gi_0199-6952250/Privateequity-a nd-corporate-governance.html)

GFH Financial Statement (2009). GULF FINANCE HOUSE BSC CONSOLIDATED FINANCIAL STATEMENTS, [online], retrieved on 13th March 2010 from GFH : (http://www.gfh.com/media-files/2010/02/16/20100216_GFH-Financial-Statement2009.pdfl)

Gulf Finance House (2010). Business. [online], retrieved on 3rd March 2010 from Gulf Finance House: (http://www.gfh.com/en/our-business/our-business.html.) 
International Financial Services London (2009). IFSL Research Private equity [online], retrieve on $7^{\text {th }}$ march 2010 from:

(http://www.ifsl.org.uk/upload/PrivateEquity2009.pdf)

Karagoez, Goeksenin (2009). Gulf Finance House, Standard \& Poor's. USA, The McGraw-Hill Company.

Maktoob Business (2010). Bahrain's GFH chairman faces \$125 mln lawsuit, [online], retrieved on $8^{\text {th }}$ March 2010 from:

(http://business.maktoob.com/20090000433650/Bahrain_s_GFH_chairman

_faces_\$125_mln_lawsuit/Article.htm)

Martin, Matthew (2010). Rescuing Bahrain's Gulf Finance House, [online], retrieved on 13th March 2010 from MEED:

(http://www.meed.com/sectors/finance/banking/rescuing-bahrains-gulf-financehouse/3004533.article)

Private Equity Council (2007). Public value, a Primer on Private Equity, [online], retrieved on $7^{\text {th }}$ march 2010 from:

(http://www.privateequitycouncil.org/wordpress/wp-

content/uploads/pec_primer_layout_final.pdf)

Reuters (2010). Bahrain GFH eyes $\$ 250$ million asset sales, [Online], retrieved on10th march 2010 from: (http://www.reuters.com/article/idUSTRE61F3AJ20100216)

Richter, F. (2010), Update 1-Bahrain's GFH posts $\$ 607 \mathrm{mln}$ loss in Q4, [Online], retrieved on 7th March 2010 from Reuters:

(http://www.reuters.com/article/idUSLDE61D0EM20100214)

Standard \& Poor's. (2010). Bahrain-based Gulf Finance House lowered to 'SD/SD' on partial debt extension, [online], retrieved on 13th March 2010 from AMEinfo :

(http://www.ameinfo.com/223728.html)

Standard \& Poor's. (2010). Bahrain-based Gulf Finance House raised to 'CCC-/C'; outlook negative, [online], retrieved on 13th March 2010 from AMEinfo :

(http://www.ameinfo.com/225743.html)

Sandwick, John (2008). Divergence of views, divergence of allocations, [online], retrieved on 9th March 2010 from Islamic Banking and Finance (http://www.sandwick.ch/Documents/Islamic\%20Wealth\%20\&\%20Asset\%20Manage ment/Publications/2008\%2006\%20Sandwick\%20in\%20Islamic\%20Banking\%20\&\%2 0Finance.pdf) 
Sankaran, K., Shahin, M. (2010). Bank of America Merill Lynch - A new year, a new company, Gulf Finance House BSC, [online], retrieved on 7th March 2010 from

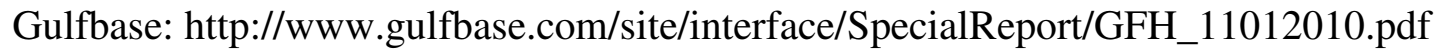

Soorani, S. (2010). Sico Research, Gulf Finance House - Fighting for survival, Outlook changed to "negative". [online], retrieved on 7th March 2010 from Gulfbase: (http://www.zawya.com/provider_permission/default.cfm?provider=sico\&storyid=pdf _240210085235)

Wouters, P. (n.d.). Islamic Private Equity Fund, [online], retrieved on $18^{\text {th }}$ February 2010 from Dow Jones Indexes:

(http://www.djindexes.com/islamic/index.cfm?go=literature)

Zawya (2010). Profile of Gulf Finance House, [online], retrieved on 13th March 2010 from Zawya:

(http://www.zawya.com/cm/profile.cfm/cid1000115/Gulf\%20Finance\%20House/ ricGFH.BSE?cc)

\section{8- Appendix}

Investment and Project launches

Some of Gulf Finance House's largest operations in the development infrastructure sector (Gulf Finance House 2010):

- Mumbia Economic Development Zone (investment volume approximately US\$ 10 billion)

- Algiers Economic Development Zone (US\$ 3 billion) (Gulf Finance House, 2010)

- Energy Cities in Qatar, Libya, India and Kazakhstan (investment volume above US\$ 11.6 billion)

- Legends in Dubai Land (US\$ 3.8 billion) (Zawya, 2010)

- Tunis Financial Harbor (US\$ 3 billion)

- Bahrain Financial Harbor (US\$1.3 billion). 